\title{
Tailed Pepper (Piper cubeba) L. berries extract reduced number of microbial population in tofu
}

\author{
${ }^{1,3}$ Alqadeeri, F. M., ${ }^{1,2}$ Abas, F., ${ }^{1}$ Shaari, K. and ${ }^{1,2 *}$ Rukayadi, Y. \\ ${ }^{1}$ Laboratory of Natural Products, Institute of Bioscience, Universiti Putra Malaysia, 43400 UPM Serdang, \\ Selangor, Malaysia \\ ${ }^{2}$ Department of Food Science, Faculty of Food Science and Technology, Universiti Putra Malaysia, 43400 \\ UPM Serdang, Selangor, Malaysia \\ ${ }^{3}$ Department of Botany, Faculty of Science, University of Sabratha, Sabratha, Libya
}

\section{Article history:}

Received: 30 September 2019

Received in revised form: 30

November 2019

Accepted: 6 November 2019

Available Online: 22 January 2020

\section{Keywords:}

Piper cubeba L. extract,

Foodborne pathogen,

Microbial population,

Natural preservative,

Tofu

DOI:

https://doi.org/10.26656/fr.2017.4(3).325

\begin{abstract}
The family of Piperaceae contains the species P. cubeba L., which has been used as a spice in countries such as Malaysia, Indonesia, India, Morocco, and Europe. A previous study has shown that crude extracts of tailed pepper ( $P$. cubeba L.) have antimicrobial activities against foodborne pathogens species. The excellent antimicrobial activity of $P$. cubeba L. berries extract makes it suitable for use as a natural preservative or sanitizer in the food. The aim of this study was to evaluate the effect of the P. cubeba L. berries extract on microbial population in tofu. The tofu samples were cut into small pieces and mixed thoroughly to ensure the homogeneity of natural microflora. Ten grams of the samples were immersed in $20 \mathrm{~mL}$ varying concentrations of $P$. cubeba $\mathrm{L}$. extract; $0.00 \%$, $0.05 \%, 0.50 \%$ and $5.00 \%$ for 1,2 and $4 \mathrm{hrs}$ at room temperature $\left(23 \pm 2^{\circ} \mathrm{C}\right)$ with the agitation of $50 \mathrm{rpm}$. At 1, 2 and $4 \mathrm{hrs}$ the numbers of total plate count (TPC), Bacillus cereus, coliform and Escherichia coli were counted. The result shows that a reduction of at least $3 \log _{10} \mathrm{CFU} / \mathrm{g}$ of TPC, Bacillus cereus., coliform and E. coli in tofu samples was observed when the samples were treated with $0.50 \%$ extract for four hours. The result suggested that $P$. cubeba L. berries extract can be used as a natural preservative to reduce the microbial load in raw food.
\end{abstract}

\section{Introduction}

Globally, the actual challenge faced by the food industry is addressing consumers' concern regarding food safety, quality and conservation of foods. This is done by limiting the use of synthetic chemical additives (Negi, 2012). A wide variety of plant products have been evaluated to determine the feasibility of using natural antioxidants to preserve and improve the overall quality of food products, especially meat and meat by-products (Shah et al., 2014).

Natural products contain ingredients that have a promising potential of new types of therapeutic agents (Newman et al., 2003). Globally, there are about 500,000 species of plants; however, considering that phytochemical investigations have been performed on only $1 \%$ of these plant species, it is very likely that novel bioactive compounds would be discovered in the future (Palombo, 2011). Piper cubeba L. is commonly known as a condiment and is widely used in food preparation as a flavor enhancer and to impart spiciness (Alharbi et al.,
2017). In the food industry, the apparent antimicrobial activities of $P$. cubeba L. extract could be exploited for use as a natural preservative or sanitizer (Junqueira et al., 2007; Khan and Siddiqui, 2007; Aneja et al., 2010; Parvez et al., 2010; Nahak and Sahu, 2011; Al-Tememy, 2013; Alsaid et al., 2013).

The scientific name of cubeb or tailed pepper (named on account of the attached stalks) is Piper cubeba $\mathrm{L}$. The tailed pepper which a perennial climbing plant is also known in Indonesia as the Javanese pepper (Al-Tememy, 2013). The pepper normally has between four and six leaves, round branches and a climbing stem, and it is usually about half an inch long and between half an inch to two inches wide (Al-Tememy, 2013). There are over 700 species under the genus Piper which can be found in both hemispheres of the earth. The family of Piperaceae contains the species $P$. cubeba L., which has been used as a spice in countries such as Indonesia, India, Morocco, and Europe since the middle ages (Silva et al., 2007). 
P. cubeba L. is used to treat illnesses, for instance, dysentery, syphilis, abdominal pain, diarrhea, enteritis, and asthma (Usia et al., 2005). Many plants from the Piper genus are used in traditional herbal medicine. Species from the Piper genus are known to have antifungal, insecticidal, anthelminthic, and antitumor properties. Polyhydroxy cyclohexanes that are isolated from $P$. cubeba L. have been shown to have tumor inhibition, antileukemic and antibiotic properties. Piperine is an alkaloid from the pyridine group and occurs naturally in plants of the Piperaceae family. Piperine is known to be utilized rather extensively in medicinal preparations, including herbal cough syrups; it that has been shown to be anti-inflammatory, antimalarial (Nahak and Sahu, 2011). Many previous studies have investigated the phytochemical constituents of Piper species, including compounds such as amides, terpenes, phenylpropanoids, benzoic acids, chromenes, lignans, phenolics, and a sequence of alkaloids (Jensen et al., 1993; Parmar et al., 1997; Wu et al., 1997). Moreover, various bioactive compounds have been identified in $P$. cubeba L. including Alkaloids/amides, lignans, neolignans terpenes and essential oils such as sabinene, beta-elemene, $\beta$-caryophyllene, epi-cubebol, and cubebol (Bos et al., 2007).

For the past decade, plants that are generally categorized as Generally Recognized as Safe (GRAS) for humans are frequently associated with food consumption (Negi, 2012). Without complementary biological aspects, the discovery of new medicinal plants/-extracts/constituents is more of pure phytochemistry (Meyer et al., 1982). Thus, plant extracts for food applications must be declared to be biologically safe prior to be consumed by humans, Therefore, the sanitizing effect of $P$. cubeba L. extract on tofu cake samples was assessed.

\section{Materials and methods}

\subsection{Tofu samples}

The tofu samples used in the present study were purchased from the local market near Universiti Putra Malaysia (UPM), Sri Kembangan, Selangor, on August 2018 and taken to the laboratory of Natural Product, Institute of Bioscience, Universiti Putra Malaysia (UPM), where immediate microbiological analysis was performed. B. cereus, Escherichia coli and coliform bacteria were analyzed according to the protocols described in the Bacteriological Analytical Manual, Food and Drug Administration. Lee et al. (2017) recommended homogenizing $10 \mathrm{~g}$ of tofu with $90 \mathrm{~mL}$ of $0.85 \%$ sterile saline $(8.5 \mathrm{~g} / \mathrm{L}$ of sodium chloride; Sigma Aldrich) for two mins using a stomacher (Laboratory Blender Stomacher 400; Seward, London, UK). Then, 1 $\mathrm{mL}$ of the homogenate was serially diluted tenfold using
$9 \mathrm{~mL}$ of $0.85 \%$ sterile saline $(8.5 \mathrm{~g} / \mathrm{L}$ of sodium chloride; Sigma Aldrich), and $1 \mathrm{~mL}$ of the diluted solution spread on each selective media. Mannitol egg yolk polymyxin agar base (Oxoid) supplemented with egg yolk emulsion was used as the selective media for $B$. cereus. The plates were incubated at $30^{\circ} \mathrm{C}-37^{\circ} \mathrm{C}$ for $24-48 \mathrm{hrs}$ and the colonies of B. cereus, E. coli, and coliforms were counted.

\subsection{P. cubeba L. berries samples and extraction}

The dried P. cubeba L. (Piperaceae) berries employed in this study was obtained from a market selling traditional herbs in Pasar Baru Bandung, Indonesia. The P. cubeba L. was collected in April 2015 in a plantation in Jatiroto, Temanggung, Central Java, Indonesia. The Department of Biology, Institut Teknologi Bandung (Indonesia) authenticated the berries on the basis of Flora of Java (Backer and Van de Brink, 1968). A voucher specimen (HBG10PC01) was stored at the Herbarium Bandungense. The procured material was air-dried and put in storage at the Laboratory of Natural Products, Institute of Bioscience (IBS), Universiti Putra Malaysia (UPM). A powerful blender (Waring, model 32 BL 80, New Hartford, USA) was used to pulverized the dried berries into fine power. The powdered P. cubeba $\mathrm{L}$. sample was stored in an airtight polyethylene plastic bag and put in storage in a $-80^{\circ} \mathrm{C}$ fridge.

The extraction of Piper cubeba L. was done utilizing the soaked method illustrated by Rukayadi et al. (2008). The organic solvent used in the extraction of $P$. cubeba L. is absolute methanol (R\&M Chemicals, 99.8\%). Dried P. cubeba L. berries of $100 \mathrm{~g}$ were ground to obtain as a powder. Sample extraction was performed using $400 \mathrm{~mL}$ room-temperature solvent and $48 \mathrm{hrs}$ of conventional shaking. Filtration of the plant extract was done using Whatman filter paper size No. 2 (Whatman International Ltd., Middlesex, England). Following this, the extracts were concentrated using a rotary vacuum evaporator (Heidolph VV2011, Schwabach, Germany) at $40^{\circ} \mathrm{C}$ for 3 -4 hrs to obtain a methanol extract of the dried P. cubeba L. berries. The temperature of the rotary evaporator was increased to $85^{\circ} \mathrm{C}$ for $2 \times 30 \mathrm{~s}$ at the end of the extraction process to ensure that the extract is methanol-free (Madiha et al., 2017). Finally, the extracts were freezedried for $48 \mathrm{hrs}$ to eliminate water.

The stock extract of methanol was primed by dispersing crude extract of P. cubeba L. in $100 \%$ dimethyl sulfoxide (DMSO) (Fisher Scientific, Leicestershire, United Kingdom) to obtain a $100 \mathrm{mg} / \mathrm{mL}$ concentration. The stock extract was put in storage at $4^{\circ}$ $\mathrm{C}$ up to the time it is ready for use. Further dilution of the solution was made using sterile deionized water, $\mathrm{ddH} 2 \mathrm{O}$ to obtain three different concentrations of $0.05 \%, 0.50 \%$ 
and $5.00 \%$ P. cubeba L. extract which were then used in the treatment of tofu samples (Rukayadi et al., 2013).

\subsection{Preparation of selective media agar}

Different selective media of three types were used for the enumeration of specific microflora in tofu samples. Plate count agar was used for the enumeration of total bacteria colonies. The selection of media was based on Microbiology Manual $\left(12^{\text {th }}\right.$ ed, Merck, Darmstadt, Germany). Table 1 shows the preparations of selective media and the appearance of bacterial colonies on the selective media.

\subsection{Treatment of tofu samples with P. cubeba L. extract solution}

The tofu samples were cut into small pieces and mixed thoroughly to ensure the homogeneity of natural microflora. Samples of $10 \mathrm{~g}$ were immersed in $20 \mathrm{~mL}$ of tap water and varying concentrations of $P$. cubeba $\mathrm{L}$. extract $(0.00 \%, 0.05 \%, 0.50 \%$ and $5.00 \%)$ for 1,2 and 4 $\mathrm{hrs}$ at room temperature $\left(23 \pm 2^{\circ} \mathrm{C}\right)$ and were agitated. A $10 \mathrm{~g}$ of the sample without immersion in any sample solvent served as the control sample. Treatments were conducted under aseptic condition. A total of $10 \mathrm{~g}$ the sample was homogenized with $90 \mathrm{~mL}$ of $0.85 \%$ sterile saline $(8.5 \mathrm{~g} / \mathrm{L}$ of sodium chloride; SigmaeAldrich) for two minutes using a stomacher. An aliquot $(1 \mathrm{~mL})$ of the homogenate was then serially diluted tenfold with $9 \mathrm{~mL}$ of $0.85 \%$ sterile saline $(8.5 \mathrm{~g} / \mathrm{L}$ of sodium chloride; SigmaeAldrich). The sample was homogenized using a stomacher machine (BagMixer 400-P, Interscience, France). The enumeration of microorganisms was performed using the spread plate method. Fifty micrograms of the dilution was spread on the selective agar plates in duplicates. The colony forming unit per $\mathrm{ml}$ (CFU/g) was counted after $24 \mathrm{hrs}$ of incubation at $37^{\circ} \mathrm{C}$ (Lee et al., 2017).

\subsection{Statistical analysis}

The experiment was performed in two replications with three repetitions each time $(n=2 \times 3)$. The data were expressed as a mean \pm standard deviation. Excel (v. 2010), Graph Pad Prism version 6.00 for Windows (v. 6.00, Graph Pad Software, San Diego, CA, USA) was employed to perform the statistical analysis. Results are given as a mean of three replicates $\pm \mathrm{SD}$. The significant difference at $P<0.05$ was established by performing ANOVA.

\section{Results and discussion}

\subsection{Extraction yield}

Dried Piper cubeba L. berries were extracted using absolute methanol $99.9 \%(\mathrm{v} / \mathrm{v})$ and the yields of the crude extract were presented in Table 2. The yield of herbal extracts are influenced by the types of soaking solvent, the ratio of soaking solvent, type of extraction technique, and soaking period (Sultana et al., 2009; Abdullah et al., 2015).

Table 2. Total yield of P. cubeba L. extract.

\begin{tabular}{|c|c|c|c|c|}
\hline $\begin{array}{c}\text { Dried } \\
\text { berries }(\mathrm{g})\end{array}$ & $\begin{array}{c}\text { Solvent } \\
\text { extraction }\end{array}$ & $\begin{array}{c}\text { Extraction } \\
\text { step }\end{array}$ & $\begin{array}{c}\text { Total Yield } \\
\text { of extract }(\mathrm{g})\end{array}$ & $\begin{array}{c}\text { Yield extract } \\
(\%)\end{array}$ \\
\hline 100 & Methanol & $\begin{array}{c}\text { First } \\
\text { extraction }\end{array}$ & 19.9 & 19.9 \\
\hline 750 & Methanol & $\begin{array}{l}\text { Second } \\
\text { extraction }\end{array}$ & 164.46 & 21.93 \\
\hline
\end{tabular}

The first and important step in utilizing herbal plant is extraction. Extraction generally yields the desired chemical compounds/components which are then subjected to further separation, purification and characterization. The basic steps involved in extraction are pre-washing of plants/parts of medicinal plants, drying, grinding, and combining the samples with extraction solvents, filtration, and finally evaporation of the solvent prior to use/storage. Samples have to be pulverized to ensure their homogeneity. Moreover, this step would produce a much higher surface area of the

Table 1. Preparations of selective media and appearance of bacterial colonies on selective media

\begin{tabular}{|c|c|c|c|}
\hline Bacteria species & Media & Preparation & Colour of bacteria colony \\
\hline B. cereus & $\begin{array}{l}\text { Polymyxin-Mannitol-Egg Yolk- } \\
\text { Phenol Red agar (Merck, Darmstadt, } \\
\text { Germany) }\end{array}$ & $\begin{array}{l}\text { Suspend } 46 \mathrm{~g} \text { in } 900 \mathrm{~mL} \text { distilled } \\
\text { water and bring to the boil to } \\
\text { dissolve completely. Sterilize by } \\
\text { autoclaving at } 121^{\circ} \mathrm{C} \text { for } 15 \mathrm{mins} \text {. }\end{array}$ & $\begin{array}{l}\text { Pink colonies surrounded with white } \\
\text { precipitate }\end{array}$ \\
\hline E. coli & $\begin{array}{l}\text { ChromoCult Coliform agar (Merck, } \\
\text { Darmstadt, Germany) }\end{array}$ & $\begin{array}{l}\text { Dissolve } 26.5 \mathrm{~g} \text { in } 1 \mathrm{~L} \text { distilled water } \\
\text { and bring to the boil to dissolve } \\
\text { completely. Sterilize by autoclaving } \\
\text { at } 121^{\circ} \mathrm{C} \text { for } 15 \text { mins. }\end{array}$ & Violet to blue colonies \\
\hline Coliform & $\begin{array}{l}\text { MacConkey (Oxoid Ltd., } \\
\text { Hampshire, England) }\end{array}$ & $\begin{array}{l}\text { Suspend } 52 \mathrm{~g} \text { in } 1 \mathrm{~L} \text { of distilled } \\
\text { water and bring to the boil to } \\
\text { dissolve completely. Sterilize by } \\
\text { autoclaving at } 121^{\circ} \mathrm{C} \text { for } 15 \text { mins }\end{array}$ & $\begin{array}{l}\text { Pink to red in colour colonies } \\
\text { surrounded by a zone of bile salt } \\
\text { precipitation }\end{array}$ \\
\hline Total plate count & $\begin{array}{l}\text { Plate Count agar (Difco, Sparks, } \\
\text { Maryland, United States) }\end{array}$ & $\begin{array}{l}\text { Suspend } 22.5 \mathrm{~g} \text { in } 1 \mathrm{~L} \text { of distilled } \\
\text { water and bring to the boil to } \\
\text { dissolve. Sterilize by autoclaving at } \\
121^{\circ} \mathrm{C} \text { for } 15 \text { mins. }\end{array}$ & White colonies \\
\hline
\end{tabular}


sample, thereby enhancing the kinetics of analytic extraction. The extraction must be done following appropriate steps to prevent loss of potential active constituents and to ensure that the components are not destroyed or distorted (Sasidharan et al., 2011).

In this study, the crude extract was obtained using absolute methanol and the yield of the crude extract is $19.90 \%$. There is no previous report regarding the yield of $P$. cubeba L. crude extract that uses methanol as a solvent. It is important to emphasise that the use of methanol as a solvent for food applications is not recommended. Even though the present study used methanol for extraction, precaution was taken to ensure that the final crude extract did not contain methanol residue. As the extraction process was almost complete, the temperature of the rotary evaporator was increased to $85^{\circ} \mathrm{C}$ for $2 \times 30 \mathrm{~s}$ (Madiha et al., 2017). Since the boiling temperature of methanol is $50^{\circ} \mathrm{C}$, the methanol is expected to completely evaporate at this temperature. This confirms that the $P$. cubeba L. crude extract obtained in this study is a methanol-free extract.

3.2 Effect of P. cubeba L. extract on microbial population in tofu

Plant products in the form of extracts, essential oils, and others with protuberant antimicrobial activities have remarkably emphasized for their possible applications in food production. This corresponds with the increasing awareness of the need to explore novel natural antimicrobial agents in food microbiology in an effort to inhibit and kill bacteria and fungal growth (Belguith et al., 2009).

Tofu is a popular soy-based food in East Asian countries and is a cheap source of high-quality protein. Tofu contains approximately $6.0 \%-8.4 \%$ protein and $79 \%-87 \%$ water and has an almost neutral $\mathrm{pH}$ (5.2-6.2). The particularly high protein and moisture content of tofu make it a very good medium for microorganisms (Ashraf et al., 1999). Microorganisms have been reported to easily contaminate tofu even when the tofu is refrigerated. Spoiled tofu has a sour taste and an unpleasant smell due to bacterial growth. Hence, compared to other products, tofu is a delicate product with a very short shelf life. The preservation of tofu is influenced by environmental factors such as bacterial load, storage temperature, air composition, and manufacturing process (Lee et al., 2017).

\subsubsection{Effect of P. cubeba L. extract on total plate count (TPC) population in tofu}

Table 3 shows the TPC bacterial count in tofu samples with filtered tap water and $P$. cubeba $\mathrm{L}$. extract at varying concentrations of $0.00 \%, 0.05 \%, 0.50 \%$ and $5.00 \%(\mathrm{v} / \mathrm{v})$ as a possible natural preservative. The initial TPC on the tofu samples were significantly reduced for 1 $\log _{10}$ CFU/g, from 6.77 \pm 0.71 to $5.44 \pm 0.43 \log _{10} \mathrm{CFU} / \mathrm{g}$ when exposed to $5.00 \%$ extract for two hours (Table 3 ). The count was further reduced to $4.34 \pm 0.08 \mathrm{Log} 10 \mathrm{CFU} /$ $\mathrm{g}$ when exposed to $5.00 \%$ extract for four hours. The tofu exposed to tap water and $0.00 \%$ extract did not show a significant reduction in the TPC at 1,2 and 4 hours of treatment time. The total plate count for exposure to $5.00 \%(\mathrm{v} / \mathrm{v})$ extract for one hour is not significantly different than those exposed to $0.50 \%, 0.05 \%$, tap water and $0.00 \%$.

Total Plate Count (TPC) is commonly used to measure the level of hygiene in food processing plants and the overall degree of bacterial contamination (Edris et al., 2015). The TPC in tofu sample is $7.69 \pm 0.11 \log _{10}$ $\mathrm{CFU} / \mathrm{g}$. The initial count for tofu samples with B. cereus, coliform and $E$. coli are $4.87 \pm 0.18,5.88 \pm 0.14$ and $6.72 \pm 0.07 \log _{10} \mathrm{CFU} / \mathrm{g}$, respectively. Previous studies have reported identifying the presence of pathogenic bacteria in tofu, such as coliform bacteria, Pseudomonas spp., E. coli, Enterococcus spp., lactic acid bacteria, $B$. cereus, Staphylococcus spp., Salmonella spp., Yersinia sp., and Cronobacter sakazakii (Ananchaipattana et al., 2012). There is also a report of Enterobacteriaceae, Enterococci, Staphylococci, and yeast being detected in tofu, where the total aerobic mesophilic count is $10^{5}$

Table 3. Effects of filtered tap water and different concentrations of $P$. cubeba L. extract on TPC in tofu samples after exposure for 1,2 and 4 hours at room temperature $\left(28 \pm 2^{\circ} \mathrm{C}\right)$.

\begin{tabular}{cccc}
\hline Bacteria & \multicolumn{3}{c}{ Total plate count $\left(\log _{10} \mathrm{CFU} / \mathrm{g}\right)$} \\
\hline Initial count & \multicolumn{3}{c}{$7.69 \pm 0.11$} \\
\hline Treatment & $1 \mathrm{hr}$ & $2 \mathrm{hrs}$ & $4 \mathrm{hrs}$ \\
\hline Tap water & $6.73 \pm 0.65^{\mathrm{Aa}}$ & $6.77 \pm 0.71^{\mathrm{Aa}}$ & $7.15 \pm 0.16^{\mathrm{Aa}}$ \\
$0.00 \%$ extract & $6.63 \pm 0.62^{\mathrm{Aa}}$ & $6.58 \pm 0.60^{\mathrm{Aa}}$ & $7.36 \pm 0.16^{\mathrm{Aa}}$ \\
$0.05 \%$ extract & $6.61 \pm 0.65^{\mathrm{Aa}}$ & $6.48 \pm 0.21^{\mathrm{Aa}}$ & $6.32 \pm 0.36^{\mathrm{Ab}}$ \\
$0.50 \%$ extract & $6.24 \pm 0.08^{\mathrm{Aa}}$ & $5.75 \pm 0.34^{\mathrm{Bb}}$ & $5.19 \pm 0.17^{\mathrm{Bc}}$ \\
$5.00 \%$ extract & $6.19 \pm 0.40^{\mathrm{Aa}}$ & $5.44 \pm 0.43^{\mathrm{Bb}}$ & $4.34 \pm 0.08^{\mathrm{Cd}}$ \\
\hline
\end{tabular}

Values are expressed as mean \pm SD. Different superscript lowercase letters in the same column are significantly different $(\mathrm{P}<0.05)$ while different superscript uppercase letters in the same row are significantly different $(\mathrm{P}<0.05)$. 
Table 4. Effects of filtered tap water and different concentrations of $P$. cubeba L. extract on Bacillus cereus in tofu samples after exposure for 1,2 and 4 hours at room temperature $\left(28 \pm 2^{\circ} \mathrm{C}\right)$.

\begin{tabular}{cccc}
\hline Bacteria & \multicolumn{3}{c}{ Bacillus cereus $\left(\log _{10} \mathrm{CFU} / \mathrm{g}\right)$} \\
\hline Initial count & \multicolumn{3}{c}{$4.87 \pm 0.18$} \\
\hline Treatment & $1 \mathrm{hr}$ & $2 \mathrm{hrs}$ & $4 \mathrm{hrs}$ \\
\hline Tap water & $4.41 \pm 0.18^{\mathrm{Aa}}$ & $4.66 \pm 0.31^{\mathrm{Aa}}$ & $4.30 \pm 0.30^{\mathrm{Aa}}$ \\
$0.00 \%$ extract & $4.33 \pm 0.12^{\mathrm{Aa}}$ & $4.66 \pm 0.43^{\mathrm{Aa}}$ & $4.16 \pm 0.43^{\mathrm{Aa}}$ \\
$0.05 \%$ extract & $3.66 \pm 0.40^{\mathrm{Ab}}$ & $3.46 \pm 0.58^{\mathrm{Ab}}$ & $3.83 \pm 0.13^{\mathrm{Ab}}$ \\
$0.50 \%$ extract & $3.13 \pm 0.31^{\mathrm{Ab}}$ & $3.33 \pm 0.37^{\mathrm{Ab}}$ & $3.09 \pm 0.17^{\mathrm{Ab}}$ \\
$5.00 \%$ extract & $3.04 \pm 0.40^{\mathrm{Ab}}$ & 0 & 0 \\
\hline
\end{tabular}

Values are expressed as mean \pm SD. Different superscript lowercase letters in the same column are significantly different $(\mathrm{P}<0.05)$ while different superscript uppercase letters in the same row are significantly different $(\mathrm{P}<0.05)$.

$\mathrm{CFU} / \mathrm{g}$, which is comparable to the result obtained in the present study (Lee et al., 2017).

\subsubsection{Effect of P. cubeba L. extract on Bacillus cereus population in tofu}

A $5.00 \%(\mathrm{v} / \mathrm{v})$ extract of B. cereus with an initial load of $4.87 \pm 0.18 \quad \log _{10} \mathrm{CFU} / \mathrm{g}$ was able to reduce bacteria count to zero after treatment for 2 and 4 hours. The count was significantly reduced to $3.33 \pm 0.37 \log _{10}$ $\mathrm{CFU} / \mathrm{g}$ when the tofu was exposed to a $0.50 \%(\mathrm{v} / \mathrm{v})$ extract for two hours and 3.09 \pm 0.17 counts after four hours of exposure. Treatment with tap water and $0.00 \%$ extract did not result in any significant reduction of $B$. cereus count (Table 4). According to the Food Standards Australia New Zealand, the permitted level of B. cereus in food is below $10^{2} \mathrm{CFU} / \mathrm{g}$. A count greater than or equal to $10^{4} \mathrm{CFU} / \mathrm{g}$ is considered unsafe and may result in immediate recall of foods for further inspection. However, in the UK the level is only regarded as hazardous if it is greater than $10^{5} \mathrm{CFU} / \mathrm{g}$. The allowable limit in the UK is below $10^{3} \mathrm{CFU} / \mathrm{g}$ (Bilung et al., 2016).

Foodborne bacteria produce endospores that are resistant to heat. They are able to grow at temperatures of between $10-48^{\circ} \mathrm{C}$, and the optimum temperature for growth range from 28 to $35^{\circ} \mathrm{C}$. Treatments for disinfection are high temperature (for canning) and lowering $\mathrm{pH}$. The pathogenesis of $\mathrm{B}$. cereus depends primarily on the dose consumed and the site of the bacteria that produce the toxin in either food or intestine. The bacterial infection is manifested as emesis and diarrhoea (Bilung et al., 2016).

\subsubsection{Effect of P. cubeba L. extract on E. coli population in tofu}

The initial count of E. coli in the tofu samples is $6.72 \pm 0.07 \log _{10} \mathrm{CFU} / \mathrm{g}$. TPC was significantly reduced to $4.63 \pm 0.34,5.25 \pm 0.27$ and $4.95 \pm 0.05 \log _{10} \mathrm{CFU} / \mathrm{g}$ when the tofu was exposed to $5.00 \%$ and $0.50 \%(\mathrm{v} / \mathrm{v})$ extract for 1, 2 and 4 hours, respectively (Table 5). A significant reduction of about $2.09 \log _{10} \mathrm{CFU} / \mathrm{g}$ was observed after one hour of treatment with $5.00 \%$ extract. Exposing the E. coli to $5.00 \%$ extracts of $P$. cubeba $\mathrm{L}$. for two and four hours resulted in the death of all E. coli. However, exposing the E. coli to $0.05 \%$ extracts for one and two hours produced similar results as exposing the bacteria to tap water and $0.00 \%$ extract.

\subsubsection{Effect of P. cubeba L. extract on coliform bacteria population in tofu}

The presence of coliforms is a general indication of sanitary condition or water contamination in the food processing environment (Edris et al., 2015). The initial coliform count was found to be greater than $B$. cereus count in tofu, which are $4.87 \pm 0.18$ and $5.88 \pm 0.14 \log _{10}$

Table 5. Effects of filtered tap water and different concentrations of P. cubeba L. extract on Escherichia coli in tofu samples after exposure for 1,2 and 4 hours at room temperature $\left(28 \pm 2^{\circ} \mathrm{C}\right)$.

\begin{tabular}{cccc}
\hline Bacteria & \multicolumn{3}{c}{ Escherichia coli $\left(\log _{10} \mathrm{CFU} / \mathrm{g}\right)$} \\
\hline Initial count & \multicolumn{3}{c}{$6.72 \pm 0.07$} \\
\hline Treatment & $1 \mathrm{hr}$ & $2 \mathrm{hrs}$ & $4 \mathrm{hrs}$ \\
\hline Tap water & $5.72 \pm 0.07^{\mathrm{Aa}}$ & $5.34 \pm 0.41^{\mathrm{Aa}}$ & $6.07 \pm 0.42^{\mathrm{Aa}}$ \\
$0.00 \%$ extract & $5.93 \pm 0.27^{\mathrm{Aa}}$ & $5.42 \pm 0.40^{\mathrm{Aa}}$ & $6.02 \pm 0.70^{\mathrm{Aa}}$ \\
$0.05 \%$ extract & $5.09 \pm 0.45^{\mathrm{Aa}}$ & $5.08 \pm 0.39^{\mathrm{Aa}}$ & $5.14 \pm 0.12^{\mathrm{Ab}}$ \\
$0.50 \%$ extract & $5.55 \pm 0.32^{\mathrm{Aa}}$ & $5.25 \pm 0.27^{\mathrm{Aa}}$ & $4.95 \pm 0.05^{\mathrm{Bc}}$ \\
$5.00 \%$ extract & $4.63 \pm 0.34^{\mathrm{Ab}}$ & 0 & 0 \\
\hline
\end{tabular}

Values are expressed as mean \pm SD. Different superscript lowercase letters in the same column are significantly different $(\mathrm{P}<0.05)$ while different superscript uppercase letters in the same row are significantly different $(\mathrm{P}<0.05)$. 
Table 6. Effects of filtered tap water and different concentrations of $P$. cubeba L. extract on coliform bacteria in tofu samples after exposure for 1,2 and 4 hours at room temperature $\left(28 \pm 2^{\circ} \mathrm{C}\right)$.

\begin{tabular}{cccc}
\hline Bacteria & \multicolumn{3}{c}{ Coliform bacteria $\left(\log _{10} \mathrm{CFU} / \mathrm{g}\right)$} \\
\hline Initial count & \multicolumn{3}{c}{$5.88 \pm 0.14$} \\
\hline Treatment & $1 \mathrm{hr}$ & $2 \mathrm{hrs}$ & $4 \mathrm{hrs}$ \\
\hline Tap water & $5.66 \pm 0.62^{\mathrm{Aa}}$ & $6.18 \pm 0.41^{\mathrm{Aa}}$ & $6.32 \pm 0.19^{\mathrm{Aa}}$ \\
$0.00 \%$ extract & $5.44 \pm 0.34^{\mathrm{Aa}}$ & $5.78 \pm 0.16^{\mathrm{Ab}}$ & $6.09 \pm 0.21^{\mathrm{Aa}}$ \\
$0.05 \%$ extract & $5.29 \pm 0.48^{\mathrm{Aa}}$ & $5.29 \pm 0.62^{\mathrm{Ab}}$ & $5.03 \pm 0.14^{\mathrm{Ab}}$ \\
$0.50 \%$ extract & $5.18 \pm 0.68^{\mathrm{Aa}}$ & $5.18 \pm 0.26^{\mathrm{Ab}}$ & $4.79 \pm 0.25^{\mathrm{Bc}}$ \\
$5.00 \%$ extract & $4.82 \pm 0.30^{\mathrm{Ab}}$ & 0 & 0 \\
\hline
\end{tabular}

Values are expressed as mean \pm SD. Different superscript lowercase letters in the same column are significantly different (P $<0.05$ ) while different superscript uppercase letters in the same row are significantly different $(\mathrm{P}<0.05)$.

$\mathrm{CFU} / \mathrm{g}$, respectively. The coliform count was significantly reduced to $5.18 \pm 0.26 \log _{10} \mathrm{CFU} / \mathrm{g}$ and $4.79 \pm 0.25$, respectively after two and four hours of treatment with a $0.50 \%$ extract. The coliform count is zero when the samples were exposed to a $5.00 \%$ extract for two and four hours. Exposure to $0.50 \%$ extract exposed for one hour did not result in any significant difference in coliform counts in contrast to exposure to tap water and $0.05 \%$ and $0.00 \%$ extracts (Table 6).

Preventing microbial spoilage of tofu is considered an important research topic in an attempt to ensure food safety (Serrazanetti et al., 2013; Rossi et al., 2016). According to Ananchaipattana et al. (2012), the sour taste of tofu is associated and characterized by its spoilage and bacterial growth. Information on the major bacteria responsible for the putrefaction of tofu is very scarce even though Acinetobacter calcoaceticus, Bacillus cereus, Klebsiella pneumoniae and Xenorhabdus luminescens have been reported to be the main causes of tofu spoilage. Likewise, coliform bacteria have been frequently identified in fresh tofu, and high levels of Escherichia coli have been identified in soybean curd being transported from the producers to retail stores (Tuttemwong and Fung, 1991; Ashraf et al., 1999).

In addition, numerous Yersiniosis outbreaks have been associated with tofu, and one case has been reported in Seattle and Washington State between December 1981 and February 1982. Several occurrences of tofu contamination with Listeria monocytogenes have also been reported (Ananchaipattana et al., 2012). In a 2010/2011 study carried out in Thailand, B. cereus was isolated from $40 \%$ of unpackaged tofu obtained from open markets $(n=74)$ and $41 \%$ of packaged tofu $(n=59)$ from supermarkets. Of the $54 \mathrm{~B}$. cereus isolates from the tofu, four of the strains have been identified to produce diarrhoeal enterotoxin (Ananchaipattana et al., 2012).

In terms of public health, tofu is classified as a ready -to-eat and potentially hazardous food. Tofu has been implicated in many outbreaks of foodborne illness. In a Yersiniosis outbreak in Seattle, the water used to process tofu was identified as a major source of contamination. An outbreak of shigellosis has also been related to contaminated tofu. Yet another incident of Listeria monocytogenes contamination has resulted in a product recall. Several studies have identified the presence of coliform bacteria in tofu (Ashraf et al., 1999). The degree of contamination by coliform bacteria, E. coli, Salmonella sp. and Enterococcus sp. in unpackaged tofu samples is considerably higher than those of packed tofu (Ananchaipattana et al., 2012).

The values reported in the present study are higher than those recommended by "The Soy Food Association of America" for soy milk, which states that mesophilic bacteria counts should not exceed 2 x $10^{4} \mathrm{CFU} / \mathrm{mL}$ (TSAA, 1996; Ribeiro et al., 2017). Rossi et al. (2016) reported the presence of mesophilic bacteria in all samples obtained from fresh tofu, and that the values are one to three Log higher than those for soybean samples obtained from the same industry. These findings showed that the processing of tofu in manufacturing industries create conditions (addition of water, grinding, coagulation, molding, etc.) that favor natural enrichment of microbial load. Any failure in the process would encourage the proliferation of unacceptable microorganisms.

Results of bacterial count on the tofu which have been exposed to different concentrations of $P$. cubeba L. for varying durations vary widely. In general, a significant reduction in bacterial population was observed at $P$. cubeba L. extract of $0.05 \%$ regardless of the duration of exposure. Interestingly, a bacterial count reduction of $3 \log _{10} \mathrm{CFU} / \mathrm{g}$ and greater were observed at $0.50 \%$ and $5.00 \%$ concentration of the extract. This shows that the reduction in the bacterial count is strongly correlated with a higher concentration of extract and treatment time.

\section{Conclusion}

In conclusion, the reduction in the bacterial count is strongly correlated with the utilization of higher 
concentration of $P$. cubeba L. extract and longer treatment time. Overall, a significant $(\mathrm{P}<0.05)$ bacterial load reduction was observed when the tofu samples were treated with a minimum concentration of $0.05 \%(\mathrm{v} / \mathrm{v})$. An extract concentration of $5.00 \%(\mathrm{v} / \mathrm{v})$ seems to be the ideal antimicrobial concentration considering in that it resulted in a $3 \log _{10}$ reduction of bacterial load. Extract with a concentration of $0.50 \%(\mathrm{v} / \mathrm{v})$ resulted in a reduction of bacterial load of at least $3 \log _{10}$. In conclusion, on the basis of exposure time and concentration of extract used to treat the tofu samples, the relative effective combinations which result in sanitizing/antimicrobial activity is $0.50 \%(\mathrm{v} / \mathrm{v}) P$. cubeba L. extract for four hours.

\section{Conflict of Interest}

The authors declare no conflict of interest.

\section{Acknowledgements}

The authors would like to acknowledge the tremendous financial support from Universiti Putra Malaysia under the Putra Grant-Putra Graduate Initiative (GPIPS/2018/9645000) and Graduate Research Fellowship for the research funding.

\section{References}

Abdullah, A., Dhaliwal, K.K., Roslan, N.N.F., Lee, C.H., Kalaiselvam, M., Radman, M., Saad, Q.H.M., Yusof, K. and Jaarin, K. (2015). The effects of Cosmos caudatus (Ulam raja) on detoxifying enzymes in extrahepatic organs in mice. Journal of Applied Pharmaceutical Science, 5(1), 82-88.

Alharbi, N.S., Khaled, J.M., Alzaharni, K.E., Mothana, R.A., Alsaid, M.S., Alhoshan, M., Dass, L.A., Kadaikunnan, S. and Alobaidi, A.S. (2017). Effects of Piper cubeba L. essential oil on methicillinresistant Staphylococcus aureus: an AFM and TEM study. Journal of Molecular Recognition, 30(1), 19. https://doi.org/10.1002/jmr.2564

Alsaid, M., Al-mofleh, I., Raish, M., Al-sobaihani, M., Al-yahya, M. and Rafatullah, S. (2013). Antiulcerogenic, anti-secretory and cytoprotective effects of Piper cubeba (L.) on experimental ulcer models in rat. International Journal of Biotechnology for Wellness Industries, 2(4), 173181. https://doi.org/10.6000/1927-3037.2013.02.04.4

Al-Tememy, T.M.K. (2013). Antibacterial activity of Piper cubeba L. fruit extracts against selected bacterial pathogens in Basrah city. Basrah Journal of Veterinary Research, 12(1), 1-10. https:// doi.org/10.33762/bvetr.2013.76184

Ananchaipattana, C., Hosotani, Y., Kawasaki, S.,
Pongswat, S., Latiful, B. M., Isobe, S. and Inatsu, Y. (2012). Bacterial contamination of soybean curd (tofu) sold in Thailand. Food Science Technology Research, 18(6), 843-848. https://doi.org/10.3136/ fstr. 18.843

Aneja, K.R., Joshi, R., Sharma, C. and Aneja, A. (2010). Antimicrobial efficacy of fruit extracts of two Piper species against selected bacterial and oral fungal pathogens. Brazilian Journal of Oral Sciences, 9(4), 421-426. https://doi.org/10.20396/bjos.v9i4.8641724

Ashraf, H. R., White, M. and Klubek, B. (1999). Microbiological survey of tofu sold in a Rural Illinois county. Journal of Food Protection, 62(9), 1050-1053. https://doi.org/10.4315/0362-028X62.9.1050

Belguith, H., Kthiri, F., Ben Ammar, A., Jaafoura, H., Ben Hamida, J. and Landoulsi, A. (2009). Morphological and biochemical changes of Salmonella hadar exposed to aqueous garlic extract. International Journal of Morphology, 27(3), 705713. https://doi.org/10.4067/S071795022009000300013

Bilung, L.M., Tahar, A.S., Shze, T.P., Jamie, S.V.F.A., Hashim, H.F., Apun, K. and Radu, S. (2016). Enumeration and molecular detection of Bacillus cereus in local indigenous and imported rice grains, Agriculture and Food Security, 5, 25. https:// doi.org/10.1186/s40066-016-0074-4

Bos, R., Woerdenbag, H.J., Kayser, O., Quax, W.J., Ruslan, K. and Elfami. (2007). Essential oil constituents of Piper cubeba L. fils. from Indonesia. Journal of Essential Oil Research, 19(1), 14-17. https://doi.org/10.1080/10412905.2007.9699217

Edris, A.M., Amin, R.A., Nassif, M.Z. and Mahmoud, M.Z. (2015). Bacterial status of fresh marketed chicken meat cuts-up. Benha Veterinary Medical Journal, 28(2), 52-57. https://doi.org/10.21608/ bvmj.2015.31863

Jensen, S., Hansen, J. and Boll, P.M. (1993). Lignans and neolignans from Piperaceae (review). Phytochemistry, 33(3), 523-530. https:// doi.org/10.1016/0031-9422(93)85442-T

Junqueira, A.P.F., Perazzo, F.F., Souza, G.H.B. and Maistro, E.L. (2007). Clastogenicity of Piper cubeba (Piperaceae) seed extract in an in vivo mammalian cell system. Genetics and Molecular Biology, 30(3), 656-663. https://doi.org/10.1590/S141547572007000400025

Khan, M. and Siddiqui, M. (2007). Antimicrobial activity of Piper fruits as herbal ingredients of Asian medicines. Natural Product Radiance, 6(2), 111113. 
Lee, D.Y., Kwon, K.H., Chai, C. and Oh, S.W. (2017). Microbial contamination of tofu in Korea and growth characteristics of Bacillus cereus isolates in tofu. Food Science and Technology, 78, 63-69. https:// doi.org/10.1016/j.lwt.2016.11.081

Madiha, I.Y., Rukayadi, Y. and Norhayati, H. (2017). Effects of extraction conditions on yield, total phenolic contents and antibacterial activity of methanolic Cinnamomum zeylanicum Blume leaves extract. International Food Research Journal, 24(2), 779-786.

Meyer, B.N., Ferrigni, N.R., Putnam, J.E., Jacobsen L.B., Nicholes, D.E. and McLaughlin, J.L. (1982). Brine Shrimp: A convenient general bioassay for active plant constituents. Journal of Medicinal Plant Research, 45(5), 31-34. https://doi.org/10.1055/s2007-971236

Nahak, G. and Sahu, R.K. (2011). Phytochemical evaluation and antioxidant activity of Piper cubeba and Piper nigrum. Journal of Applied Pharmaceutical Science, 1(8), 153-157.

Negi, P.S. (2012). Plant extracts for the control of bacterial growth: Efficacy, stability and safety issues for food application. International Journal of Food Microbiology, 156(1), 7-17. https://doi.org/10.1016/ j.ijfoodmicro.2012.03.006

Newman, D.J., Cragg, G.M. and Snader, K.M. (2003). Natural products as sources of new drugs over the period 1981-2002. Journal of Natural Products, 66 (7), 1022-1037. https://doi.org/10.1021/np0300961

Palombo, E.A. (2011). Traditional medicinal plant extracts and natural products with activity against oral bacteria: potential application in the prevention and treatment of oral diseases. Evidence-Based Complementary and Alternative Medicine, 2011, 115. https://doi.org/10.1093/ecam/nep067

Parmar, V.S., Jain, S.C., Bisht, K. ., Jain, R., Taneja, P. and Jha, A. (1997). Phytochemistry of the genus Piper. Phytochemistry, 46, 597-673. https:// doi.org/10.1016/S0031-9422(97)00328-2

Parvez, M., Gayasuddin, M., Basheer, M. and Janakiraman, K. (2010). Screening of Piper cubeba (Linn) fruits for anti-ulcer activity. International Journal of PharmTech Research, 2(1), 1128-1132.

Ribeiro, T.T.B.C., Costa, G and Costa, M. (2017). Microbial contamination in industrial tofu. Ciência Rural, Santa Maria, 47, e20160234. https:// doi.org/10.1590/0103-8478cr20160234

Rossi, F., Felis, G.E., Martinelli, A., Calcavecchia, B. and Torriani, S. (2016). Microbiological characteristics of fresh tofu produced in small industrial scale and identification of specific spoiling microorganisms. LWT - Food Science and Technology, 70, 280-285. https://doi.org/10.1016/ j.lwt.2016.02.057

Rukayadi, Y., Lau, K.Y., Zainin, N.S., Zakaria, M. and Abas, F. (2013). Screening of antimicrobial activity of tropical edible medicinal plant extracts against five standard microorganisms for natural food preservatives. International Food Research Journal, 20(5), 2905-2910.

Rukayadi, Y., Shim, J.S. and Hwang, J.K. (2008). Screening of Thai medicinal plants for anticandidal activity. Mycoses, 51(4), 308-312. https:// doi.org/10.1111/j.1439-0507.2008.01497.x

Sasidharan, S., Chen, Y., Saravanan, D., Sundram, K.M. and Yoga Latha, L. (2011). Extraction, isolation and characterization of bioactive compounds from plant extracts. African Journal of Traditional, Complementary and Alternative Medicine, 8(1), 110. https://doi.org/10.4314/ajtcam.v8i1.60483

Serrazanetti, D.I., Ndagijimana, M., Miserocchi, C., Perillo, L. and Guerzoni, M.E. (2013). Fermented tofu: Enhancement of keeping quality and sensorial properties, Food Control, 34(2), 336 - 346. https:// doi.org/10.1016/j.foodcont.2013.04.047

Shah, M.A., John, S., Bosco, D. and Mir, S.A. (2014). Plant extracts as natural antioxidants in meat and meat products. Meat Science, 98(1), 21-33. https:// doi.org/10.1016/j.meatsci.2014.03.020

Silva, M.L.A., Coimbra, H.S., Pereira, A.C., Almeida, V.A., Lima, T.C., Costa, E.S. and Bastos, J.K. (2007). Evaluation of Piper cubeba extract, (-) cubebin and its semi-synthetic derivatives against oral pathogens. Phytotherapy Research, 21(5), 420422. https://doi.org/10.1002/ptr.2088

Sultana, B., Anwar, F. and Ashraf, M. (2009). Effect of extraction solvent/technique on the antioxidant activity of selected medicinal plant extracts. Molecules, 14(6), 2167-2180. https:// doi.org/10.3390/molecules14062167

Tuttemwong, K. and Fung, D.Y.C. (1991). Microbiological study of Tofu. Journal of Food Protection, 54(3), 212-216. https:// doi.org/10.4315/0362-028X-54.3.212

Usia, T., Watabe, T., Kadota, S. and Tezuka, Y. (2005). Metabolite-cytochrome P450 complex formation by methylenedioxyphenyl lignans of Piper cubeba: mechanism-based inhibition. Life Sciences, 76, 2381 -2391. https://doi.org/10.1016/j.1fs.2004.12.005

Wu, Q., Wang, S., Tu, G., Feng, Y. and Yang, J. (1997). Alkaloids from Piper puberullum. Phytochemistry, 44, 727-730. https://doi.org/10.1016/S0031-9422(96) 00585-7 